\title{
Effect of Shelling Methods on the Shelling Efficiency, Product Quality, Functional and Sensory Properties of Melon (Egusi) Seeds Sold in Aba, Abia State, Nigeria
}

\author{
Akusu O.M. and Chibor B.S.
}

\begin{abstract}
Local Aba made melon shelling machine type I (sample B) and improved Aba made melon shelling machine type 2 (sample C) were used to shell melon seeds and compared with hand shelling method (sample A). The shelling efficiency, quality of shelled melon seeds, functional properties of the seed flours and sensory properties of egusi soups prepared from the melon seeds were determined. The results revealed that sample $A$ gave the highest shelling efficiency of $92.25 \%$, followed by sample $\mathrm{C}(90.42 \%)$ and the least was sample B $(\mathbf{8 0 . 8 5 \%})$. For the quality of shelled melon seeds, sample A gave the highest score of $95.88 \%$, following by sample $C(94.46 \%)$ while sample $B$ gave the least score of $79.84 \%$. There was no significant difference $(P>0.05)$ in the proximate composition of the melon seeds obtained from the three shelling methods (samples $A, B$ and $C$ ). There were no significant difference $(\mathrm{P}>0.05)$ in all the selected functional properties between samples $A$ and $C$ while sample $B$ had significantly lower values in all the functional properties that were studied. The mean scores for overall acceptability of egusi soup prepared from the shelled melon seeds were; samples A (7.95), sample $B$ (6.02) and sample $C$ (7.72). Functional and sensory properties of the melon seeds shelled by the improved Aba made melon shelling machine type 2 compared favourably with the hand shelled melon seeds. Hence, it can be recommended for commercial operations to meet the demands of industrial and commercial markets.
\end{abstract}

Index Terms - Melon seeds, shelling efficiency, egusi soup, functional and sensory properties.

\section{INTRODUCTION}

Melon (Citrullus vulgaris) commonly known as "egusi" is extensively cultivated and consumed in Nigeria and West Africa especially use in the preparation of soups as a thickener [1]. Egusi seed is rich in protein, polyunsaturated fatty acids (PUFA), vitamins and minerals [2]. It has a high water and oil holding capacity and forms thick and stable emulsion and could find a place in the food industry as it holds promise for its oil content, thickening and stabilizing properties and could be used for food product fortification. Sobowale et al. [3] stated that processing of melon seed is essential to further diversify its uses. Melon seed shelling involves removal of the outermost husk from the melon seed to obtain the melon kernel (egusi seed). Shelling of melon seed is an important unit operation in its processing to obtain good quality and unbroken shelled melon seeds. In Nigeria, most of the egusi seed sold in the markets are

Published on January 20, 2020.

Authors are with the Department of Food Science and Technology,

Rivers State University, Nkpolu- Oroworukwo, Port Harcourt, Nigeria

( Corresponding email: akusu.monday@yahoo.com ) obtained by the traditional or manual hand shelling method. This traditional hand shelling method is tedious and time consuming; thus, limiting the availability of shelled melon seeds in the market and its commercial production. The traditional method of shelling also causes bruises and serious injury to the human fingers coupled with low output. Adekunle et al. [4], reported that the inability to effectively shell melon seed in order to meet the required capacity necessary for industrial utilization has been a hindrance to its use for large scale production and product diversification.

Mechanised shelling method which involves advanced automated shelling machine that has an efficient shelling performance, less time consuming has become imperative for small and medium scale egusi farmers. In Nigeria, substantial research has been carried out on the design and fabrication of mechanised melon shelling machines [5-9]. Despite all these efforts at producing a good melon shelling machine over the years, most of these machines were found to have low shelling efficiency, high percentage of seed breakages. Okokon et al. [9], reported that the test conducted on most of the locally designed and fabricated melon shelling machines showed that their shelling efficiencies rate were below $30 \%$. Noted setback been; wasting of the cotyledon through breakage, unhygienic outlook of the shelled melon seed, swelling ability, rancidity and souring of soups prepared from such melon seeds. Sobowale et al. [3], reported that seed moisture content and the speed of the shelling machine are the main factors that affect the quality of the shelled melon seed, shelling efficiency was shown to increase with increase in moisture content of unshelled melon seed and a decrease in shelling speed. An optimum moisture content of $18.32 \%$ and a shelling speed of $1500 \mathrm{rpm}$ was recommended to be appropriate [10]. There have been several complaints among Nigerian women about the use of machined shelled egusi in food preparation. These complaints include, poor hygienic outlook of the melon seeds, high percentage of broken kernels, low swelling ability and rancidity/souring of soups compared to egusi soups prepared from hand shelled melon seeds. Majority of current melon shelling is done with hand shelling. Whereas to the best of the authors' knowledge, there is only one type of melon shelling machine, fabricated in Aba, Abia State, Nigeria that is used commercially. This machine seems to be an improvement on all the other locally fabricated shelling machine in Nigeria.

Thus, this study aimed to evaluate the shelling efficiency, melon quality, proximate, functional and sensory 
properties of local (Type 1) and improved (Type 2) Aba fabricated melon shelling machines and compared them with the hand shelled melon seeds.

\section{MATERIALS AND METHODS}

\section{A. Materials}

Unshelled melon seeds were purchased from new market in Aba, Abia State and transported to Food Chemistry Laboratory in the Department of Food Science and Technology, Rivers State University, Port Harcourt, Nigeria. Chemicals used for the analysis were of analytical grade and were obtained from the same Department.

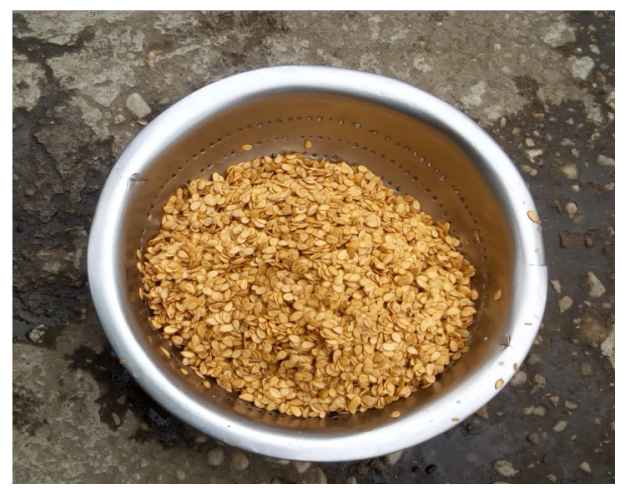

Plate 1: Soaked Melon Seeds

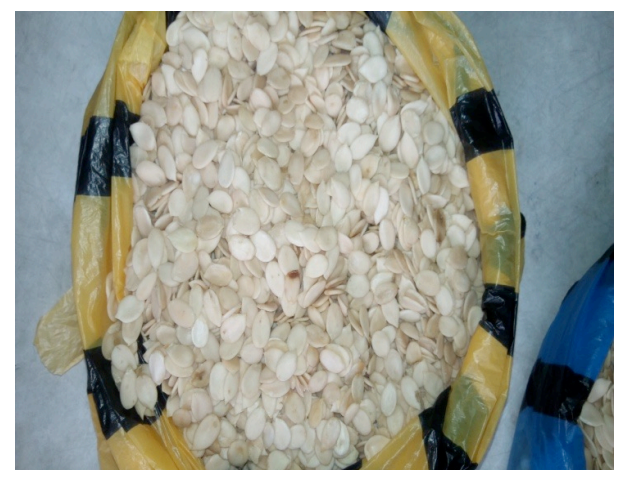

Plate 3: Hand Shelled Melon Seeds

\section{B. Production of Hand Shelled Melon Seeds}

The traditional hand melon shelling method was used. Six kilograms $(6 \mathrm{~kg})$ of unshelled melon seeds were sorted and sprinkled with water, air dried for $10 \mathrm{~min}$ and shelled manually. The shelled melon seeds containing the shells were dried for $2 \mathrm{~h}$, then winnowed and sorted into shells, shelled whole seeds, unshelled seeds and broken seeds. The weight of the fractions were determined for calculation of shelling efficiency within $20 \mathrm{~min}$ of shelling. The shelled unbroken seeds were oven dried at $50^{\circ} \mathrm{C}$ for $12 \mathrm{~h}$ using the air oven (model QUB 305010G, Gallenkamp, UK).

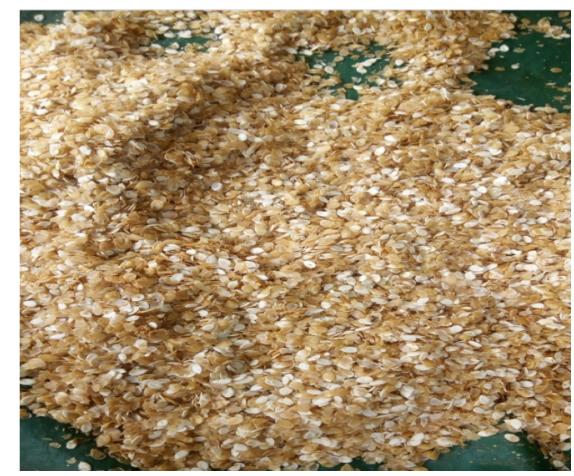

Plate 2: Sun Dried Melon Mixture Before Separation

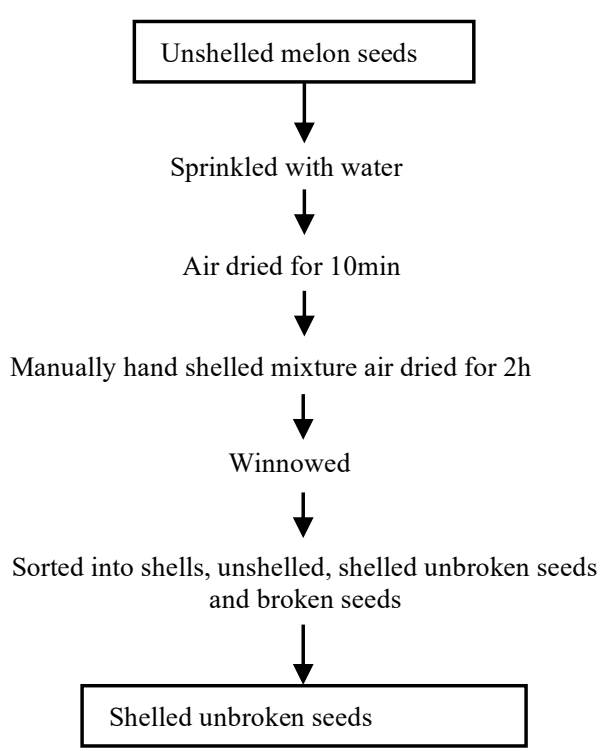

Figure 1: Flow Chart for Manual Hand Shelled Melon Seeds

with improved Aba made (Type 2) melon shelling machines. The shelling was done within 20min, the shelled mixture was then dried for $2 \mathrm{~h}$, winnowed and sorted into shells, unbroken shelled seeds, unshelled seeds and broken seeds. Their weight were determined 
and used for the calculation of shelling efficiency. The unbroken seeds were oven dried at $50^{\circ} \mathrm{C}$ for $12 \mathrm{~h}$ in a hotair fan oven (model QUB, 305010G, Gallenkamp, UK) and ground using a laboratory mill (Numex pep grinding mill, India).

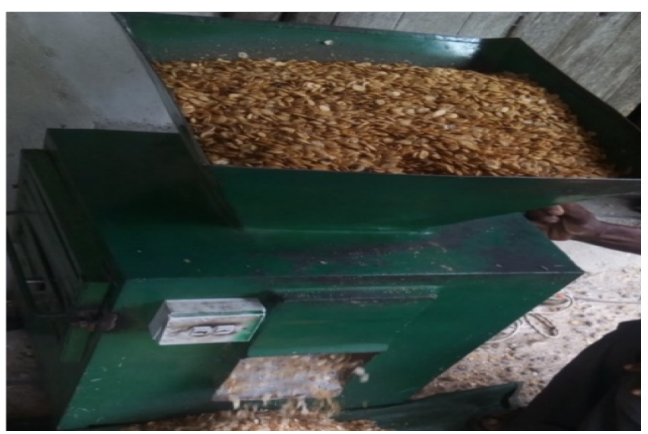

Plate 5: Improved Aba Melon Shelling Machine

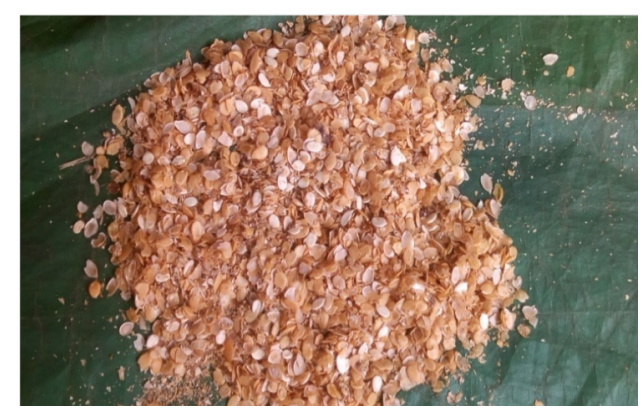

Plate 7: Mixture After Shelling By Machine

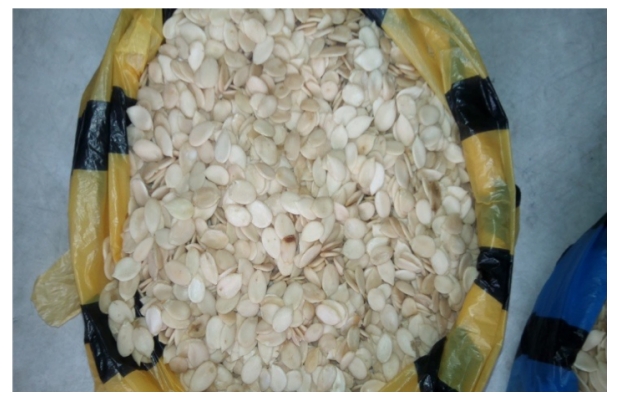

Plate 9: Improved Aba Machine Shelled Melon Seeds 


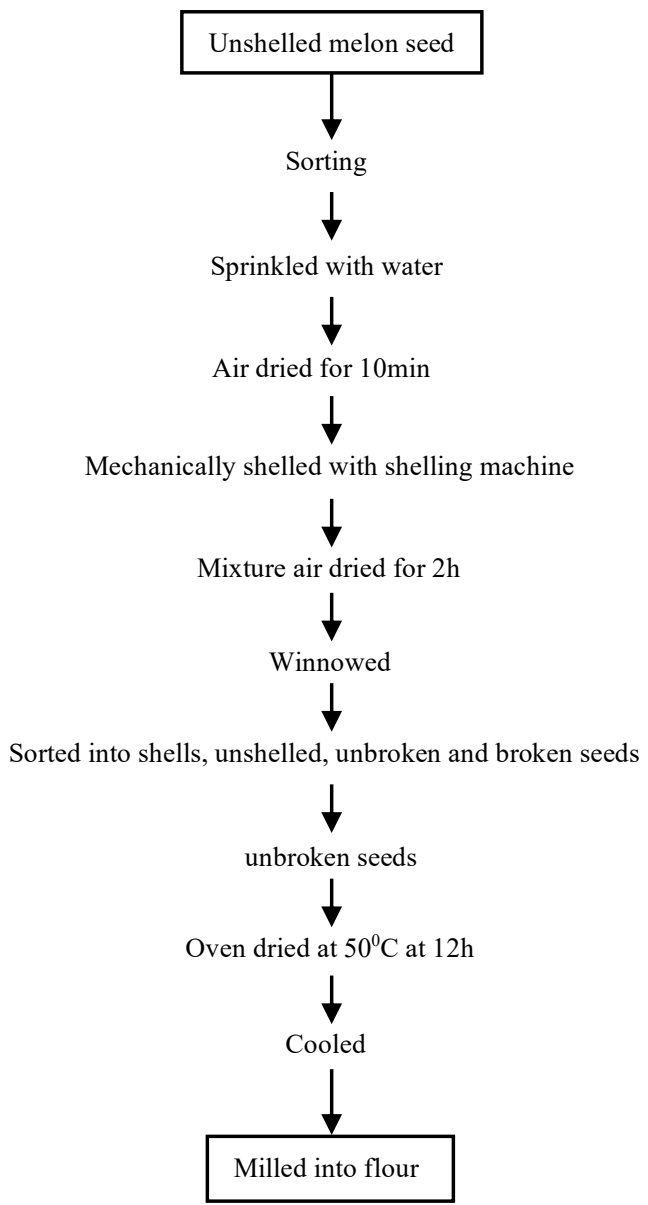

Figure 2: Flow chart for machine shelled melon seeds

\section{Determination of Shelling Efficiency and Melon} Seed Quality

The shelling efficiency of both manual and machine shelled melon seeds were determined by calculating the ratio of completely shelled melon seed to the total weight of unshelled melon seeds fed into the machine hopper or manually hand shelled. Total pieces produced or expected outputs were used for the calculation and included unshelled melon, melon shells, broken melon and unbroken wholesome melon seeds. The weight of unshelled melon seed input, shells produced, unbroken shelled melon seeds, unshelled melon seeds after shelling and broken shelled melon seeds were equally determined and used for the calculation.

The shelling efficiency, effectiveness, productivity and quality of shelled melon seeds were then calculated with the use of the following equation;

\section{Melon Seeds'Shelling Efficiency = Weight of shelled melon seed mixtures-unshelled melon seeds Total weight of melon seeds shelled (input)}

where;
Melon seed mixtures $=$ Unbroken shelled melon seeds + broken shelled melon seeds + melon shells - unshelled melon seeds

\section{Shelled Melon Seed Quality =}

Weight of shelled whole (unbroken) melon seeds

Total weight of melon seeds shelled (input)

\section{E. Chemical Properties}

Moisture, total ash, crude fibre, either extract and crude protein were determined according to AOAC [11] standard procedures. The factor $\mathrm{N}$ x 6.25 was used for conversion of nitrogen to crude protein. Carbohydrate content was calculated by difference.

\section{F. Functional Properties}

Selected functional properties such as water and oil absorption capacity, viscosity, swelling power and foam capacity were determined on the melon seed flour. Water and oil absorption capacities were determined according to the method of Benchart [12], viscosity was determined according to the method of Fleming et al. [13], foam capacity was determined according to the method of Onwuka [14] and swelling power was determined according to the method of Takashi and Sieb [15]. 
TABLE 1: RECIPE FOR MELON SOUP (EGUSI SOUP)

\begin{tabular}{ll}
\hline Ingredients & Weight/volume \\
\hline Melon seed flour & $200 \mathrm{gm}$ \\
Palm oil & $60 \mathrm{ml}$ \\
Water & $700 \mathrm{ml}$ \\
Onion & $20 \mathrm{gm}$ \\
Maggi cube & $3.5 \mathrm{gm}$ \\
Pepper & $1.5 \mathrm{gm}$ \\
Salt & $0.2 \mathrm{gm}$ \\
\hline Source: Akusu and Kiin-Kabari [16]
\end{tabular}

\section{G. $\quad$ Preparation of Melon Soup (Egusi) Soup}

Palm oil was heated in a cooking pot for $2 \mathrm{~min}$, then chopped onion was added and finally melon seed flour added, heated and stirred at regular intervals for $15 \mathrm{~min}$. After which, $700 \mathrm{ml}$ beef stock was added, maggi, pepper and salt were added to taste.

\section{H. Sensory Properties}

A panel of 20 persons who are used to melon (egusi) soup were selected for the sensory evaluation of the soup prepared with the melon seed flours obtained from the three shelling methods. A 9-point hedonic scale with $9=$ like extremely, $5=$ neither like or dislike and $1=$ like extremely was used for the evaluation of the prepared soups for colour, appearance, thickness, taste, aroma and overall acceptability. The soups were served to the panelists in the Food and Nutrition Laboratory of the Food Science and Technology Department at room temperature $\left(28 \pm 2^{\circ} \mathrm{C}\right)$.

\section{Statistical Analysis}

The data obtained were subjected to Analysis of Variance (ANOVA) using Statistical Package for Social Science (SPSS) version 20.0 software 2011. All the analysis were conducted in triplicate and means separated using Duncan multiple range test.

\section{RESULTS AND DISCUSSION}

\section{A. Shelling Efficiency}

Shelling efficiency, productivity, effectiveness and quality of shelled melon seeds of the three methods of melon shelling is presented in Table 2. The shelling efficiency of the melon seeds ranged from $0.10 \%$ for manual hand shelling (Sample A), 53.45\% for local Aba made melon shelling machine type 1 (sample B) to $58.75 \%$ for improved Aba made melon shelling machine type 2 (sample C). The same trend was observed for melon shelling effectiveness. The productivity of the shelling methods ranged from $79.50 \%$ for sample A, $76.76 \%$ for sample B to $78.18 \%$ for sample C. The quality of shelled melon seeds ranged from 95.58 $94.46 \%$ for samples A and C, respectively. Shittu and Ndrika [17], recorded maximum shelling efficiency of $95 \%$ and further reported that the shelling efficiency increased with increase in moisture content of the unshelled melon and seeds after machine shelling. They achieved maximum efficiency at the moisture content of $26.6 \%$ and at $2,190 \mathrm{rpm}$ shelling speed. The results obtained in this study revealed that the shelling efficiency could be improved if the moisture content of the unshelled melon seeds was increased to $26 \%$ by prolong soaking. Egbe et al. [18], recommended complete soaking for $30 \mathrm{~min}$. The quality of shelled melon seeds as represented by the percentage of broken or damaged seed could also be improved upon by increasing the moisture content of the unshelled melon seeds. Shittu and Ndrika [17]; Oluwole and Adedeji [10], reported that percentage seed damaged decreased with increase in melon seed moisture content. Sobowale et al. [3], stated that at low moisture content, the unshelled melon seeds are brittle which make them to be susceptible to mechanical damage during shelling.

TABLE 2: SHELLING EFFICIENCY AND PRODUCT QUALITY OF DIFFERENT METHODS OF MELON SHELLING

\begin{tabular}{llll}
\hline & \multicolumn{3}{c}{ Shelling Methods } \\
\cline { 2 - 4 } Shelled Melon and Melon Shells & $\mathrm{A}$ & $\mathrm{C}$ & $\mathrm{C}$ \\
\hline Unshelled melon seeds (input) (kg) & $25.07 \pm 0.002^{\mathrm{a}}$ & $25.07 \pm 0.002^{\mathrm{a}}$ & $25.07 \pm 0.002^{\mathrm{a}}$ \\
Whole shelled melon seeds (kg) & $15.02 \pm 0.421^{\mathrm{a}}$ & $11.85 \pm 0.002^{\mathrm{b}}$ & $14.40 \pm 0.402^{\mathrm{b}}$ \\
Broken melon seeds (kg) & $4.62 \pm 0.001^{\mathrm{c}}$ & $7.14 \pm 0.002^{\mathrm{a}}$ & $5.45 \pm 0.000^{\mathrm{b}}$ \\
Melon shells (kg) & $4.46 \pm 0.001^{\mathrm{a}}$ & $3.68 \pm 0.000^{\mathrm{c}}$ & $4.02 \pm 0.002^{\mathrm{b}}$ \\
Unshelled melon seeds & $0.96 \pm 0.002^{\mathrm{c}}$ & $2.40 \pm 0.000 \mathrm{a}$ & $1.20 \pm 0.003^{\mathrm{b}}$ \\
Melon seeds shelling efficiency (\%) & $92.25 \pm 0.001^{\mathrm{a}}$ & $80.85 \pm 0.031^{\mathrm{c}}$ & $90.42 \pm 0.023^{\mathrm{b}}$ \\
Shelled melon seeds quality (\%) & $60.00 \pm 0.000^{\mathrm{a}}$ & $47.26 \pm 0.000^{\mathrm{c}}$ & $57.44 \pm 0.001^{\mathrm{b}}$ \\
Moisture content of unshelled melon seeds (\%) & $17.00 \pm 0.002^{\mathrm{a}}$ & $17.00 \pm 0.002^{\mathrm{a}}$ & $17.00 \pm 0.002^{\mathrm{a}}$ \\
\hline
\end{tabular}

Mean values bearing different superscript in the same row differs significantly $(\mathrm{P}<0.05)$, \pm standard deviation of triplicate determinations. Key:

$\mathrm{A}=$ Manual hand shelling, $\mathrm{B}=$ Local Aba made melon shelling machine, $\mathrm{C}=$ Improved Aba made melon shelling machine

\section{B. Proximate Composition}

The result of the study revealed that there were no significant different $(\mathrm{p}<0.05)$ in the proximate compositions of the melon seeds shelled by the three shelling methods as shown in Table 3. This result is similar with that reported by Abbah et al. [2] for proximate properties of melon seed samples. This is an indication that proximate properties of melon seeds is not effected by any form of shelling method. Moisture, ash and crude fibre values of melon seeds obtained from the three shelling methods observed in this study is in agreement with those reported by Ajilola et al. [19] while crude protein values are low compare to that reported by Bankole and Joda [20]. This could be associated to the drying or processing method adopted by Bankole and Joda or the maturity stage of the melon seeds used in these different studies. 
TABLE 3: PROXIMATE COMPOSITIONS OF MELON SEED FLOUR SHELLED BY DIFFERENT METHODS

\begin{tabular}{|c|c|c|c|c|c|c|}
\hline Sample & Moisture (\%) & Ash (\%) & $\begin{array}{l}\text { Crude protein } \\
(\%)\end{array}$ & Crude fibre $(\%)$ & Fat (\%) & Carbohydrate (\%) \\
\hline A & $5.96 \pm 0.020^{\mathrm{a}}$ & $3.54 \pm 0.015^{\mathrm{a}}$ & $28.96 \pm 0.515^{\mathrm{a}}$ & $6.98 \pm 0.025^{\mathrm{a}}$ & $49.24 \pm 0.230^{\mathrm{a}}$ & $7.09 \pm 0.200^{\mathrm{a}}$ \\
\hline B & $6.43 \pm 0.025^{\mathrm{a}}$ & $3.33 \pm 0.200^{\mathrm{a}}$ & $28.87 \pm 0.035^{\mathrm{a}}$ & $7.33 \pm 0.020^{\mathrm{b}}$ & $47.22 \pm 0.180^{c}$ & $6.88 \pm 0.125^{\mathrm{a}}$ \\
\hline
\end{tabular}

Mean values bearing different superscript in the same column differ significantly $(\mathrm{P}<0.05), \pm$ standard deviation of triplicate determinations. Key:

$\mathrm{A}=$ Manual hand shelled melon seed, $\mathrm{B}=$ Local Aba made melon shelled seed, $\mathrm{C}=$ Melon seeds obtained from the improved Aba made melon shelling machine.

\section{Functional Properties}

The result of the selected functional properties of melon seed flours shelled via three different shelling methods is presented in Table 4. Water absorption capacities (WAC) represent the ability of a product to associate with water under conditions where water is limited while oil absorption capacity (OAC) is an estimate of fat binding ability of proteins especially in melon seeds. Giami et al. [21] defined oil/fat absorption capacities as the difference in the flour weight before and after its oil absorption. Other researchers noted that oil/fat absorption capacities is an important functional property, since oil acts as flavor retainer and also increases soft texture to mouth feel of foods [22] and equally important because of their storage stability and particularly to determine the stage of rancidity development [23].

The study revealed that water and oil absorption capacities of the melon seed flours were within the ranges of $0.56-0.77 \mathrm{~g} / \mathrm{ml}$ and $0.93-1.52 \mathrm{~g} / \mathrm{ml}$, respectively. The values for WAC reported here are low while OAC values are within the ranges of those reported by Akusu and Kiin-Kabari [16] for melon seed flour. Shelling methods and the season in which these research were carried out could be responsible for these variations in the water and oil absorption capacities of the reported melon seed fours. The study further revealed that there were no significant difference $(\mathrm{P}<0.05)$ in water and oil absorption capacity, foam capacity, viscosity and swelling power between the hand peeled melon seeds (sample A) and sample C (improved Aba made melon shelling machine. Whereas, sample B (local Aba made melon shelling machine) had significantly $(\mathrm{P}>0.05)$ lower values in all the selected functional properties that were studied. The result in this study could be the reason behind the high preference of hand peeled melon seeds over machine shelled melon seeds. Complaints has been arising by the Nigerian homemakers that machine shelled melon seeds are dirty in outlook, low in swelling ability and contain a lot of broken seeds which leads to rancidity and souring of egusi soups. Significantly $(\mathrm{P}<$ 0.05 ) low swelling power of $1.62 \mathrm{~g} / \mathrm{cm}$ recorded in sample B compare to other samples confirms the serials of complaints by homemakers with regards to the low swelling ability of machine shelled melon seeds. PeterIkechukwu et al. [24] also recorded $1.36 \mathrm{~g} / \mathrm{ml}$ swelling power of machine shelled melon seeds which is in agreement with that obtain in this study. The result of this investigation have revealed that the improved Aba made melon shelling machine have the ability to eliminate these complaints with regards to the negative effects of local machine shelled melon seeds use in cooking egusi soup.

TABLE 4: SELECTED FUNCTIONAL PROPERTIES OF MELON SEED FLOUR SHELLED BY DIFFERENT METHODS

\begin{tabular}{llllll}
\hline $\begin{array}{l}\text { Shelling } \\
\text { method }\end{array}$ & $\begin{array}{l}\text { Water absorption } \\
(\mathrm{g} / \mathrm{ml})\end{array}$ & $\begin{array}{l}\text { Oil absorption } \\
(\mathrm{g} / \mathrm{ml})\end{array}$ & $\begin{array}{l}\text { Foam } \\
\text { capacity }\end{array}$ & $\begin{array}{l}\text { Viscosity } \\
(\mathrm{P} . \mathrm{as})\end{array}$ & $\begin{array}{l}\text { Swelling power } \\
(\mathrm{g} / \mathrm{cm})\end{array}$ \\
\hline $\mathrm{A}$ & $0.77 \pm 0.020^{\mathrm{a}}$ & $1.52 \pm 0.025^{\mathrm{a}}$ & $44.50 \pm 0.035^{\mathrm{a}}$ & $32.80 \pm 0.040^{\mathrm{a}}$ & $3.32 \pm 0.035^{\mathrm{a}}$ \\
$\mathrm{B}$ & $0.56 \pm 0.025^{\mathrm{b}}$ & $0.93 \pm 0.025^{\mathrm{b}}$ & $32.34 \pm 0.020^{\mathrm{b}}$ & $24.81 \pm 0.0430^{\mathrm{b}}$ & $1.62 \pm 0.020^{\mathrm{b}}$ \\
$\mathrm{C}$ & $0.76 \pm 0.020^{\mathrm{a}}$ & $1.37 \pm 0.025^{\mathrm{a}}$ & $44.15 \pm 0.125^{\mathrm{a}}$ & $31.91 \pm 0.340^{\mathrm{a}}$ & $3.22 \pm 0.180^{\mathrm{a}}$ \\
\hline
\end{tabular}

Mean values bearing different superscript in the same column differ significantly $(\mathrm{P}<0.05), \pm$ standard deviation of triplicate determinations Key:

$\mathrm{A}=$ Manual hand shelled melon seeds, $\mathrm{B}=$ Local Aba made melon shelled seeds, $\mathrm{C}=$ Melon seeds obtained from the improved Aba made melon shelling machine.

\section{Sensory Properties}

The mean sensory scores of egusi soups prepared with melon seeds obtained from different shelling methods is shown in Table 5. The report of the study revealed that there were no significant difference $(\mathrm{P}<0.05)$ between samples $A$ and $C$ in all the sensory properties evaluated while sample $\mathrm{B}$ had significantly $(\mathrm{P}>0.05)$ low score compared to the control sample. Although, the taste of the prepared soup samples were not affected by the melon shelling methods. This study has revealed that melon seeds shelled using the improved Aba made melon shelling machine have the capacity to reduce bruises and serious injuries to human fingers caused by hand peeling, increase the output of melon seeds in the market, as well as having the ability to compare favourably with hand peeled melon seeds in soup making which meets the sensory needs of the Nigerian homemaker. 
TABLE 5: MEAN SENSORY SCORES OF THE MELON SOUP

\begin{tabular}{llllll}
\hline Samples & Aroma & Taste & Appearance & Thickness & Overall Acceptability \\
\hline A & $7.70 \pm 0.001^{\mathrm{a}}$ & $7.65 \pm 0.002^{\mathrm{a}}$ & $7.45 \pm 0.000^{\mathrm{a}}$ & $7.05 \pm 0.002^{\mathrm{a}}$ & $7.95 \pm 0.001^{\mathrm{a}}$ \\
B & $7.20 \pm 0.002^{\mathrm{b}}$ & $7.56 \pm 0.002^{\mathrm{a}}$ & $6.82 \pm 0.002^{\mathrm{b}}$ & $5.20 \pm 0.002^{\mathrm{b}}$ & $6.02 \pm 0.002^{\mathrm{b}}$ \\
C & $7.50 \pm 0.002^{\mathrm{a}}$ & $7.59 \pm 0.002^{\mathrm{a}}$ & $7.40 \pm 0.002^{\mathrm{a}}$ & $6.95 \pm 0.002^{\mathrm{a}}$ & $7.72 \pm 0.002^{\mathrm{a}}$ \\
\hline
\end{tabular}

Mean values bearing different superscript in the same column differ significantly $(\mathrm{P}<0.05), \pm$ standard deviation of triplicate determinations. Key:

$\mathrm{A}=$ Manual hand shelled melon seeds, $\mathrm{B}=$ Local Aba made melon shelled seeds, $\mathrm{C}=$ Melon seeds obtained from the improved Aba made melon shelling machine.

\section{CONCLUSION}

The three shelling methods adopted in this study revealed a significant effects on the shelling efficiency and the quality of the melon seeds while proximate properties of the three sampled melon seeds were not affected. Functional and sensory properties of the melon seeds shelled with the improved Aba made melon shelling machine (type 2) compared favourably with the hand peeled melon seeds. Hence, it is recommended for commercial operations in order to meet the demands of industrial and commercial markets.

\section{REFERENCES}

[1] Bankole, S.A., Adenusi, A.A., Lawal, O.S., Adesanya, O.O. (2010). Occurrence of aflatoxin B1 in food products derivable from 'egusi' melon seeds consumed in South Western Nigeria. Food Control, 21, 974-976.

[2] Abbah, O.C., Sanni, M. and Ejembi, D.O. (2014). Nutritional aspects of egusi melon (Citrullus colocynthis L). Asian Journal of Science and Technology, 5(3), 176-180.

[3] Sobowale SS, Adebiyi JA1, and Adebo OA1 (2015). Design, Construction and Performance Evaluation of a Melon Seeds Sheller. Journal of Food Processing and Technology, 6(7), 15. Doi: 10.4172/2157-7110.1000463

[4] Adekunle, A.S., Ohijeagbon, O.I. and Doluegun, H. (2009). Development and performance evaluation of manually and motorized operated melon shelling machine using impact technique. Journal of Engineering Science and Technology Review, 2(1), 12-17.

[5] Fashina, A.B. (1971). The Design and Development of a Melon Sheller. Project for B.Sc Agriculture Hons. University of Ife, Nigeria.

[6] Odigbon, E.U. (1979). Impact of melon shelling machine. Transaction of the ASAE: $1264-1269$.

[7] Fadamiro, I. (1999). Design and Construction of a Manually Operated Melon Sheller. Mechanical Engineering Department, University of Ilorin, Nigeria.

[8] Obienwu, D.S. (2002). Design, Construction and Testing of an Electrically Powered Melon Sheller. M. Eng. Thesis, Department of Mechanical Engineering, University of Ilorin.

[9] Okokon, F.B., Ekpenyong, E., Nwaukwa, C., Akpan, N., Abam, F.I. (2010). Impact force of melon during shelling. Agricultural Engineering International: CIGR Journal, 12:182 -185 .

[10] Oluwole, G.O. and Adedeji, A.S. (2012). Effect of moisture content and inner drum rotation speed on the shelling performance of a melon sheller. Journal of Science and Technology, 2, 21-26.

[11] AOAC (2012). Association of Official Analytical Chemist. Method of Analysis, $18^{\text {th }}$ edition. Washington, D.C.

[12] Benchat, L.R. (1977). Functional and electrophonic characteristics of succinvtazed peanut flour protein. Journal of Agriculture and Food-Chemistry, 25, 258-260.

[13] Fleming, S.C., Sosulski, F.N., and Haman, N.W. (1975). Gelation and thickening phenomena of vegetable protein. Journal of Food Science, 40, 805-807.

[14] Onwuka, G.I. (2005). Food Analysis and Instrumentation. Theory and Practice, $1^{\text {st }}($ Edn). H.G. Support Press, Lagos, Nigeria. Pp. 64-69.
[15] Takashi, S. and Sieb, P.A. (1988). Paste and gel properties of prime corn and wheat starches with and without-native lipids. Cereal chemistry, 65:1-6.

[16] Akusu M.O. and Kiin-Kabari D.B. (2015). Comparative studies on the physicochemical and sensory properties of watermelon (Citrullus lanatus) and melon (Citrullus vulgaris) seed flours used in "EGUSI" soup preparation. Journal of Food Research, 4(5), 1-8. URL: http://dx.doi.org/10.5539/jfr.v4n5p1

[17] Shittu, S.K. and Ndrika, V.I.O. (2012). Development and Performance Test of a Melon (Egusi) Seed Shelling Machine. Department of Agricultural Engineering, Faculty of Engineering, Bayero University Kano, Nigeria.

[18] Egbe, D.E., Mayah, T.F., Ebot, E.G., Egbe, P.A. and Abraham, J.P. (2015). Performance evaluation and improvement on a melon seed shelling machine. World Journal of Agricultural Science and Engineering, 1, 1-10.

[19] Ajibola, O.O., Eniyemo, S.E. Fasina, O.O. and Adeko K.A. (1990). Mechanical extraction of oil from melon seeds. Journal of Agricultural Research, 45,1.

[20] Bankole, S.A. and Joda, A.O. (2004). Effect of lemon grass powder and essential oil on mould deterioration and aflatoxin contamination on melon seeds. African Journal of Biotechnology, 3, 52-59.

[21] Giami S. Y., Okonkwo V. I. and Akusu M. O., Chemical composition and functional properties of raw, heat-treated and partially proteolysed wild mango (Irvingia gabonensis) seed flour. Food Chemistry. 49, 237-243 (1994).

[22] Ubbor S. C. and Akobundu E. N. T., Quality characteristics of cookies from composite flours of watermelon seed, cassava and wheat, Pakistan Journal of Nutrition. 8, 1097-1102 (2009).

[23] Siddiq M., Ravi R., Harte J.B. and Dolan K. D., Physical and functional characteristics of selected dry bean (Phaseolus vulgaris L.) flours. LWT-Food Science and Technology. 43, 232- 237 (2010).

[24] Peter-Ikechukwu A, Ojukwu M, Kabuo N.O., Omeire G.C., Bede E.N. Comparative evaluation of proximate compositions, functional and physicochemical properties of raw melon seeds of five members of cucurbitaceae family. American Journal of Food Science and Nutrition. Vol. 3, No. 1, 2016, pp. 8-17. 


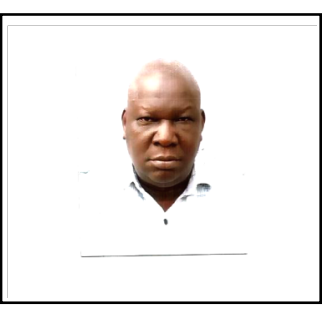

Monday Ohwesiri AKUSU was born in Eku, Delta State Nigeria on 4th March, 1957.

Degrees: He obtained his Ph.D degree in Food Science and Technology at Rivers State University, Port Harcourt in 2014. M. Phil in Food Science and Technology, Rivers State University, Port Harcourt, 1989 and H.N.D also in Food Science and Technology, Rivers State University, Port Harcourt, 1982.

Career: He is an Associate Professor (Reader) in Food Science and Technology, Rivers State University and has been lecturing in this Department for over 30 years. Several courses has been and still being taught by him.

Dr. Akusu is a member of Nigerian Institute of Food Science and Technology (NIFST). He have over 40 publications appearing in all search gates (Google Scholar, Reasearchgate, Acadenia.edu, Google Search, etc). Among them are few of;

Akusu OM, Kiin-Kabari DB and Ebere CO (2016). Quality characteristics of orange/pineapple fruit juice blends. American Journal of Food Science and Technology, 4(2), 43-47. Doi:10.12691/ajfst-4-2-3

Akusu OM, Wordu GO and Obiesie C (2019). Effects of Fat Modification on the Physicochemical Properties and Fatty Acid Profile of Shortenings Formulated with African Pear (Dacryodes edulis) Pulp Oil and Tallow Tree (Allanblackia floribunda) Seed Oil. International Journal of Nutritional Science and Food Technology, 5(2), 12-19.

Akusu OM, Kiin-Kabari DB and Isah EM (2020). Anti-nutrients, Bioaccessibility and Mineral Balance of Cookies Produced from Processed Sesame Seed Flour Blends. International Journal of Food Science and Nutrition Engineering, 10(1), 1-11 Doi: $10.5923 /$ j.food.20201001.01

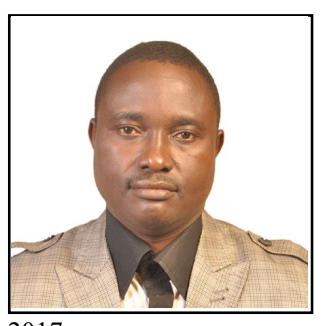

Bariwere Samuel CHIBOR was born in Buan, Rivers State, Nigeria on 21 st December, 1970.

Degrees: Ph.D. in Food Processing and Engineering, Micheal Okpara University of Agriculture, Umudike, Nigeria (2020; in view)

M.Sc. in Food Processing and Storage Technology, Rivers State University, Port Harcourt, Nigeria,

PGD in Chemical Engineering, Rivers State University, Port Harcourt, Nigeria, 1997 and B.Sc. in Food Science and Technology, Rivers State University, Port Harcourt, Nigeria, 1994. Career: Process Engineer, Food product development and optimization consultant for private companies.

Published articles: Effect of chemical interesterification on the physicochemical characteristics and fatty acid profile of bakery shortening produced from shea butter and fluted pumpkin seed oil blend. American Journal of Food Science and Technology, 6(4), 187-194. (Chibor, B.S., Eke-Ejiofor, J. and Kiin-Kabari, D.B, 2018).

Physicochemical properties and fatty acid profile of shea butter and fluted pumpkin seed oil, a suitable blend in bakery fat production. International Journal of Nutrition and Food Sciences, 6(3), 122-128. (Chibor, B.S., Kiin-Kabari, D.B. and Eke-Ejiofor, J. 2018).

In-Vitro Protein Digestibility and Amino Acid Content of Ogiri Produced from Three Varieties of Melon (Citrullus lanatus, Cucumis melo and Cucumeropsis mannii) Seeds. Proceedings of the $6^{\text {th }}$ NIFST South-East Regional Food Summit (ReFoST), Aba, Nigeria. Pp 1-3. (Akusu, M.O. and Chibor, B.S.2019).

Mr. CHIBOR, Department of Food Science and Technology, Rivers State University, Port Harcourt, Nigeria, Secretary and Member of Nigerian Institute of Food Science and Technology (NIFST). 